\title{
ANALISIS KONEKTIVITAS JARINGAN TRANSPORTASI UDARA NASIONAL
}

\author{
Gunawan ${ }^{1}$, Rully Medianto ${ }^{2}$ \\ Program Studi Teknik Penerbangan \\ Sekolah Tinggi Teknologi Adisutjipto (STTA) \\ guns797@gmail.com
}

\begin{abstract}
The airport as flight network node is the starting point and the end of the movement of people/goods. The airport can also be a transit point before continuing the journey to the destination. The closure of the airport due to force majeure such as a disaster or terrorism may disrupt the national air transportation network. The effects of the closure of an airport to the national air transportation network depends on the level of connectivity of the airport.

This study aimed to quantify the connectivity between two airports in the national air transportation network. Based on the connectivity data, it can be determined that appropriate mitigation strategies during an airport closure due to force majeure.
\end{abstract}

Keywords: Connectivity, Networks, National air transportation.

\begin{abstract}
Abstrak
Bandar udara sebagai simpul jaringan penerbangan merupakan titik awal dan berakhirnya pergerakan orang/barang. Bandar udara juga dapat menjadi tempat transit sebelum melanjutkan perjalanan ke tempat tujuan. Penutupan bandara akibat force majeur semisal bencana ataupun terorisme dapat mengganggu jaringan transportasi udara nasional. Efek dari penutupan sebuah bandara terhadap jaringan transportasi udara nasional tergantung dari tingkat konektivitas bandara tersebut.

Penelitian ini bertujuan untuk menghitung konektivitas antar bandara dalam jaringan transportasi udara nasional. Berdasar pada data konektivitas tersebut maka dapat ditentukan strategi yang tepat guna mitigasi saat terjadi penutupan bandara akibat force majeur.
\end{abstract}

Kata kunci: Konektivitas, Jaringan, Transportasi udara nasional.

\section{Pendahuluan}

Negara Kesatuan Republik Indonesia merupakan negara kepulauan terbesar di dunia, dengan jumlah pulau 17.508 buah yang berada diantara benua Asia dan Australia, luas wilayah daratan $\pm 2.012 .402 \mathrm{~km}^{2}$ dan luas wilayah perairan $\pm 5.877 .879 \mathrm{~km}$ dengan panjang garis pantai $\pm 81.000 \mathrm{~km}$. Banyaknya pulau dan letaknya yang memisahkan dua benua, diperlukan transportasi udara untuk membangun konektivitas dan memobilisasi daerah-daerah tersebut guna pemerataan pembangunan dan pemeliharaan keutuhan Negara Kesatuan Republik Indonesia (NKRI)

Indonesia memiliki banyak sumberdaya alam yang tersebar di seluruh wilayahnya, juga memiliki tempat wisata terbaik di dunia seperti Bali, bahkan Candi Borobudur pernah menjadi salah satu keajaiban dunia yang menjadi pusat perhatian seluruh bangsa di dunia. Potensi sumber daya alam dan pariwisata tersebut secara tidak langsung menyebabkan daya tarik tersendiri sehingga orang cenderung untuk melakukan perjalanan dengan tujuan masingmasing. 
Moda transportasi yang dapat spontan, bebas, mempunyai kapasitas tak terbatas dan selalu tersedia, menyebabkan transportasi dapat membuat perubahan suatu ruang yang sudah lama. Sehingga munculnya transportasi membuat perbedaan aktifitas ekonomi suatu wilayah dengan wilayah lainnya (Merlin, 1992 dalam Rodrigue, 2006).

Wilayah Indonesia yang banyak dipisahkan oleh perairan, jumlah penduduk serta aktifitas sosial-ekonomi yang tidak merata pada pulau-pulau di Indonesia dapat menyebabkan kesejahteraan masyarakat menjadi tidak merata. Salah satu faktor ketidakmerataan ini disebabkan oleh transportasi, karena interaksi ruang dan keterkaitan ekonomi antar pulau sangat ditentukan oleh peran dan tatanan transportasi nasional (Jinca, 2002). Karena itu, peran angkutan udara sebagai salah satu moda transportasi sangat mempengaruhi pertumbuhan ekonomi di Indonesia.

Interaksi antar wilayah tercermin pada keadaan fasilitas transportasi serta aliran orang, barang, maupun jasa (Hurst, 1974). Transportasi merupakan tolak ukur dalam interaksi keruangan antar wilayah dan sangat penting peranannya dalam menunjang proses perkembangan suatu wilayah (Haggett, 2001).

Jaringan transportasi antar daerah yang memungkinkan bagi pemindahan barang dan jasa atau orang dari satu tempat ke tempat lainnya merupakan indikator konektivitas antara daerah yang satu dengan daerah lain.

Bandara sebagai simpul jaringan penerbangan yang merupakan tempat awal dan berahirnya pergerakan orang/barang, dan bandara juga merupakan akses keluar masuknya ke suatu daerah. Dengan demikian konektivitas antar bandara dapat menunjukkan konektivitas suatu daerah. nasional

Untuk itu perlu dianalisis konektivitas antar bandara dalam jaringan transportasi udara

\section{Metodologi}

\subsection{Tahapan Penelitian}

Tahapan proses penelitian seperti digambarkan pada diagram berikut:

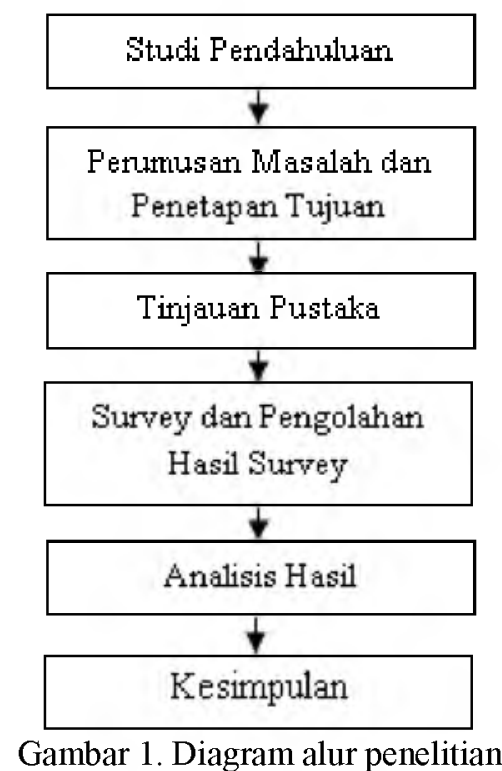




\subsection{Aksesibilitas dan Mobilitas}

Aksesibilitas adalah konsep yang menggabungkan suatu sistem pengaturan tataguna lahan secara geografis dengan sistem jaringan transportasi. Aksesibilitas adalah suatu ukuran kenyamanan bagaimana lokasi tataguna lahan berinteraksi satu dengan yang lain dan bagaimana mudah dan susahnya lokasi tersebut dicapai melalui sistem jaringan transportasi. (Black, 1981).

Pernyataan mudah bagi sesorang belum tentu mudah bagi orang lain, begitu juga dengan pernyataan susah karena pernyataan tersebut sangat subyektif dan kualitatif. Untuk itu diperlukan ukuran kinerja kuantitatif yang dapat menyatakan aksesibilitas atau kemudahan. Sedangkan mobilitas adalah ukuran kemampuan seseorang untuk bergerak yang dinyatakan dalam kemampuan membayar biaya transportasi.

Aksesibilitas ada yang menyatakannya dengan jarak, jika suatu tempat berdekatan dengan tempat lainnya, dikatakan aksesibilitas antara kedua tempat tersebut tinggi. Sebaliknya, jika kedua tempat sangat berjauhan, aksesibilitas antara keduanya rendah. Jadi, tataguna lahan yang berbeda pasti memiliki aksesibilitas yang berbeda pula karena aktivitas tataguna lahan tersebut tersebar dalam ruang secara tidak merata.

Akan tetapi peruntukan lahan tertentu seperti bandar udara, lokasinya tidak bisa sembarangan dan biasanya terletak jauh di luar kota (karena ada batasan dari segi keamanan, pengembangan wilayah, dan lain-lain). Dikatakan aksesibilitas ke bandar udara tersebut pasti akan selalu rendah karena letaknya jauh di luar kota. Namun meskipun letaknya jauh, aksesibilitas ke bandar udara dapat ditingkatkan dengan menyediakan sistem transportasi yang dapat dilalui dengan kecepatan tinggi sehingga waktu tempuhnya menjadi pendek.

Dengan demikian penggunaan jarak sebagai ukuran aksesibilitas diragukan, sehingga penggunaan waktu tempuh merupakan kinerja yang lebih baik dibandingkan dengan jarak dalam menyatakan aksesibilitas. Dapat disimpulkan bahwa suatu tempat yang berjarak jauh belum tentu dapat dikatakan mempunyai aksesibilitas rendah atau suatu tempat yang berjarak dekat mempunyai aksesibilitas tinggi karena terdapat faktor lain dalam menentukan aksesibilitas yaitu waktu tempuh.

Kualitas pelayanan transportasi suatu tata guna lahan berbeda-beda, sistem jaringan transportasi di suatu daerah mungkin lebih baik dibandingkan dengan daerah lainnya dari segi kuantitas (kapasitas) maupun kualitas (frekuensi pelayanan). Contohnya, pelayanan angkutan umum biasanya lebih baik di daerah Indonesia dan bagian barat dibandingkan dengan di daerah Indonesia bagian timur.

Skema sederhana yang memperlihatkan kaitan antara berbagai hal, yang menerangkan mengenai aksesibilitas dapat dilihat pada tabel berikut (Black, 1981):

Tabel 1. Klasifikasi Tingkat Aksesibilitas

\begin{tabular}{cccc}
\hline Jarak & Jauh & Aksesibilitas rendah & Aksesibilitas menengah \\
\cline { 2 - 3 } & Dekat & Aksesibilitas menengah & Aksesibilitas tinggi \\
\hline Kondisi Prasarana & Sangat jelek & Sangat baik \\
\hline & Sumber: (Black, 1981)
\end{tabular}

Tataguna lahan yang saling berdekatan dan hubungan transportasi antar tataguna lahan tersebut mempunyai kondisi baik, maka aksesibilitas tinggi. Sebaliknya, jika aktivitas tersebut saling terpisah jauh dan hubungan transportasinya jelek, maka aksesibilitasnya rendah. Beberapa kombinasi diantaranya mempunyai aksesibilitas menengah. 
Faktor aksesibilitas memegang penting dalam upaya perkembangan wilayah sebab tanpa didukung oleh sistem transportasi, sarana dan prasarana transportasi yang memadai, maka perkembangan suatu daerah akan sulit berkembang.

Adapun faktor-faktor yang mempengaruhi besar atau kecilnya suatu indeks aksesibilitas adalah sebagai berikut:

1. Konektivitas antara daerah yang satu dengan daerah lain adalah adanya berbagai jaringan antara daerah yang memungkinkan bagi pemindahan barang dan jasa atau orang dari satu tempat ke tempat lainnya.

2. Topografi. Kondisi alam yang memiliki karakteristik wilayah yang berbeda dengan daerah lainnya.

3. Tersedianya jaringan jalan antar daerah baik kondisi maupun jenis jalan yang mendukung dalam mengakses wilayah.

4. Kuantitas dan kualitas jalan untuk mencapai ke kawasan.

5. Keefektifan sistem jaringan yang dapat di akses oleh penduduk setempat.

\subsection{Konektivitas}

IATA telah mengembangkan indikator konektivitas untuk mengukur tingkat integrasi dengan jaringan transportasi udara global. Indikator tersebut menunjukkan banyaknya tujuan, frekuensi penerbangan untuk setiap tujuan dan jumlah koneksi selanjutnya yang tersedia untuk masing-masing tujuan. Konektivitas meningkat sejalan dengan jumlah tujuan yang meningkat, peningkatan frekuensi layanan dan/atau semakin banyaknya jumlah koneksi lanjutan yang dilayani oleh bandar udara tujuan (IATA, 2007). Metode IATA ini selanjutnya diterapkan untuk mencari tingkat konektivitas bandara-bandara di dalam Jaringan Penerbangan Nasional.

Indikator konektivitas jaringan penerbangan nasional didasarkan pada jumlah kursi yang tersedia untuk setiap tujuan. Jumlah kursi yang tersedia tersebut selanjutnya diberikan bobot sesuai dengan ukuran dari bandara tujuan yang diukur dari jumlah penumpang yang dilayani setiap tahunnya.

Pembobotan untuk setiap bandara tujuan tersebut memberikan indikasi tingkat kepentingan ekonomi dan jumlah koneksi lanjutan yang dapat disediakan. Sebagai contoh, Bandara Internasional Soekarno-Hatta yang merupakan bandara tersibuk dan terbesar di Indonesia diberikan bobot 1 sedangkan Bandara Internasional Ngurah Rai yang melayani penumpang dengan jumlah $20 \%$ dari jumlah penumpang Bandara Internasional SoekarnoHatta diberikan bobot 0,2 . Bila sebuah bandara menyediakan 1000 kursi dengan tujuan ke Bandara Internasional Soekarno-Hatta maka bobot totalnya menjadi 1000, namun dengan jumlah kursi yang sama tujuannya adalah Bandara Internasional Ngurah Rai maka diberikan bobot total 200

Bobot total tersebut selanjutnya dijumlahkan untuk semua tujuan dan dibagi dengan 1000 (sebagai faktor skala) untuk menentukan indikator konektivitas. Secara umum rumus indikator konektivitas dinyatakan sebagai:

\section{$\Sigma($ Frekuensi $\times$ Ketersediaan Kursi per Penerbangan $\times$ Bobot Bandara Tujuan $) / 1000$}

Tingginya indikator konektivitas menunjukkan tingginya derajat akses terhadap Jaringan Penerbangan Nasional. Indikator ini juga menunjukkan pentingnya sebuah bandara dilihat dari banyaknya rute penerbangan yang dilayani dan akses terhadap koneksi lanjutan dengan rute yang beragam. 
Besarnya dampak yang harus diterima oleh Sistem Jaringan Penerbangan Nasional apabila ada bandara yang tidak beroperasi dapat dilihat dari indikator konektivitas bandara tersebut. Semakin tinggi nilai konektivitasnya maka semakin besar dampaknya terhadap Sistem Jaringan Penerbangan Nasional. Dari sini terlihat pula bahwa apabila bandara yang tidak beroperasi tersebut adalah bandara pengumpul maka dampaknya juga akan lebih besar dibanding bandara pengumpan.

Apabila bandara pengumpan tidak beroperasi maka pesawat dapat diarahkan mendarat di bandara alternatif terdekat dan selanjutnya penumpang melanjutkan menuju bandara/kota tujuan dengan moda lainnya misal kereta api, jalan darat, penyeberangan atau pun laut.

\section{Hasil dan Pembahasan}

\subsection{Konektivitas Bandara Transit}

Pemilihan bandara transit guna menunjang konektivitas moda transportasi lain ke kota tujuan memperhatikan beberapa hal sebagai berikut:

1. Kelaikan bandara untuk menunjang operasi pesawat udara, di dalamnya termasuk panjang rumway, kekerasan rumway, lebar taxiway, ketersediaan parking stand, peralatan navigasi dan kapasitas terminal penumpang

2. Jarak yang tidak terlalu jauh dengan kota tujuan. Dengan jarak yang cukup pendek maka penumpang akan semakin cepat mencapai kota tujuan.

3. Ketersediaan moda transportasi lainnya guna mencapai kota tujuan. Semakin beragam moda transportasi yang tersedia maka akan semakin baik.

4. Ketersediaan angkutan penunjang untuk mencapai simpul transportasi moda lainnya dari bandara transit dengan jarak tempuh yang tidak terlalu jauh.

5. Ketersesuaian jadwal kedatangan di bandara transit dengan jadwal keberangkatan moda lain dengan mempertimbangkan waktu tempuh dari bandara transit ke simpul moda lain tersebut.

Bandara-bandara di Pulau Jawa memiliki konektivitas yang tinggi dengan moda transportasi lain terutama dengan moda darat yang terdiri dari angkutan jalan dan kereta api. Beberapa bandara di Pulau Jawa juga telah memiliki sub terminal yang menyediakan angkutan otobus dan siap mengantarkan penumpang menuju kota-kota terdekat seperti di Bandara Soekarno-Hatta di Tangerang dan Adisutjipto di Yogyakarta.

Angkutan kereta api di Pulau Jawa memberikan konektivitas yang tinggi terutama dari sisi waktu tempuh. Bahkan Bandara Adisutjipto di Yogyakarta terhubung langsung dengan Stasiun Kereta Api yang dapat digunakan untuk mengangkut penumpang tujuan ke Solo. Gambar 2 menunjukkan jalur Kereta Api yang ada di Pulau Jawa.

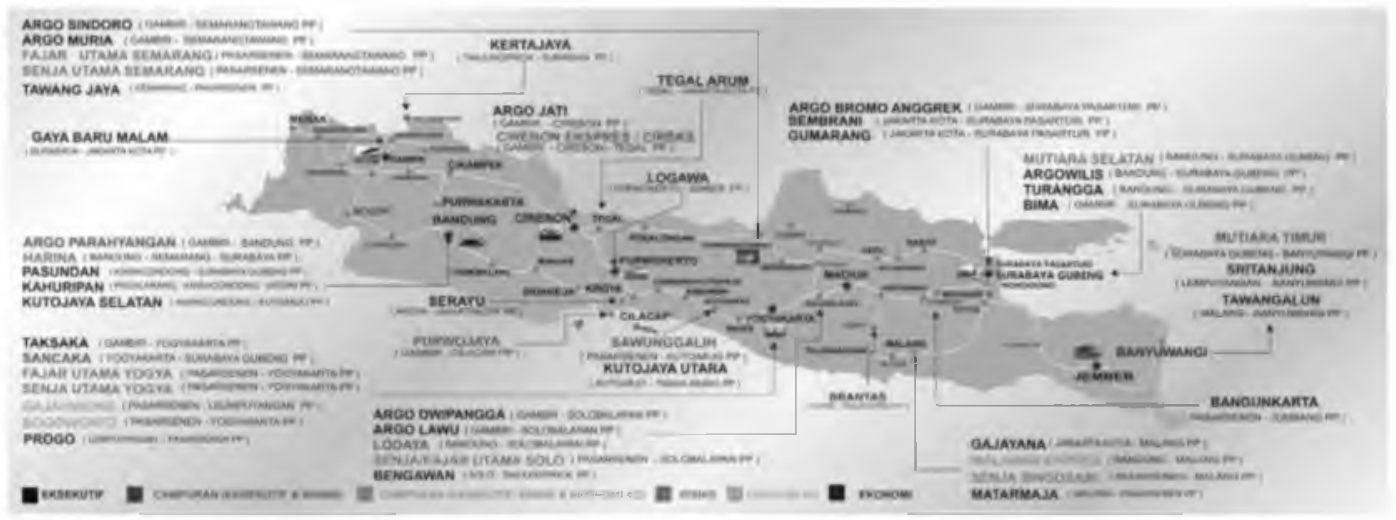

Gambar 2. Jalur Kereta Api di Pulau Jawa 
Konektivitas dengan moda transportasi lain di Pulau Sumatera juga cukup baik yang ditunjang oleh prasarana jalan raya yang menghubungkan kota-kota di Pulau Sumatera. Beberapa simpul juga dihubungkan oleh angkutan kereta api walau dengan rute yang minim dan sebagian besar ditujukan untuk angkutan komoditi. Antara Bandara Kualanamu dengan pusat Kota Medan juga telah terhubung oleh Kereta Api Bandara. Jalur Kereta Api di Pulau Sumatera ditunjukkan di Gambar 3.

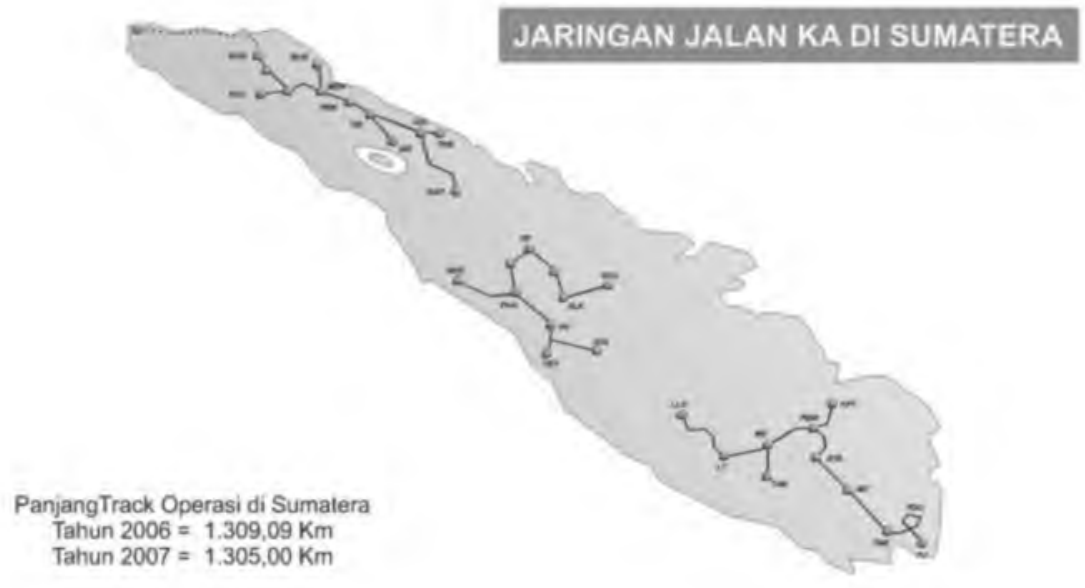

Gambar 3. Jalur Kereta Api di Pulau Sumatera

Konektivitas bandara transit menggunakan moda transportasi lain dengan kota tujuan di pulau lainnya seperti Kalimantan dan Sulawesi ditunjang oleh jaringan Jalan Raya antar kota tanpa tersedianya jalur Kereta Api. Bahkan untuk Pulau Papua beberapa kota hanya bisa diakses oleh angkutan udara seperti halnya Kota Wamena. Sedangkan untuk pulau-pulau lainnya yang lebih kecil angkutan laut seperti angkutan kapal dan angkutan penyeberangan menjadi penyokong konektivitas antarmoda dengan kota lainnya. Sampai dengan tahun 2012 terdapat 109 lintasan penyeberangan yang dioperasikan PT.ASDP Indonesia Ferry (Persero) menggunakan 51 unit Kapal, 24 lintasan dioperasikan BUMD menggunakan 10 unit kapal dan 2 lintasan dioperasikan swasta (dengan proses lelang) memakai 1 unit kapal (Dit. Hubdar, 2012). Kondisi eksisting penyeberangan di Indonesia diperlihatkan di Gambar 4.

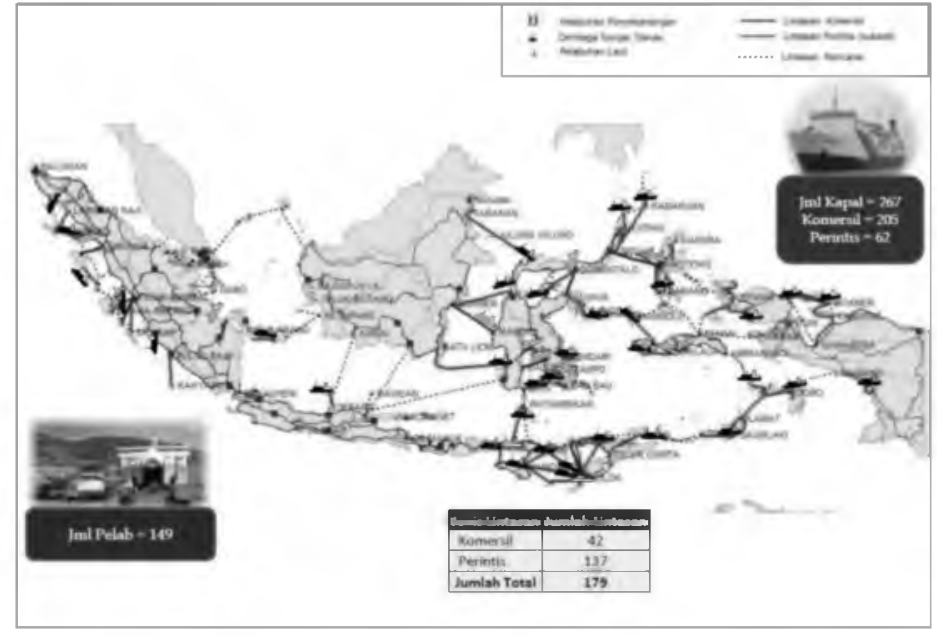

Gambar 4. Kondisi Eksisting Penyeberangan (Sumber: Ditjen Hubdar, 2013) 
Permasalahan utama dalam integrasi antarmoda terutama dengan angkutan laut adalah masih kurangnya akses menuju pelabuhan dan frekuensi jadwal pelayaran yang masih minim. Hal ini menyebabkan lamanya waktu tempuh menuju pelabuhan dan waktu tunggunya. Kondisi akses pendukung pelabuhan di Indonesia ditunjukkan di Gambar 5.

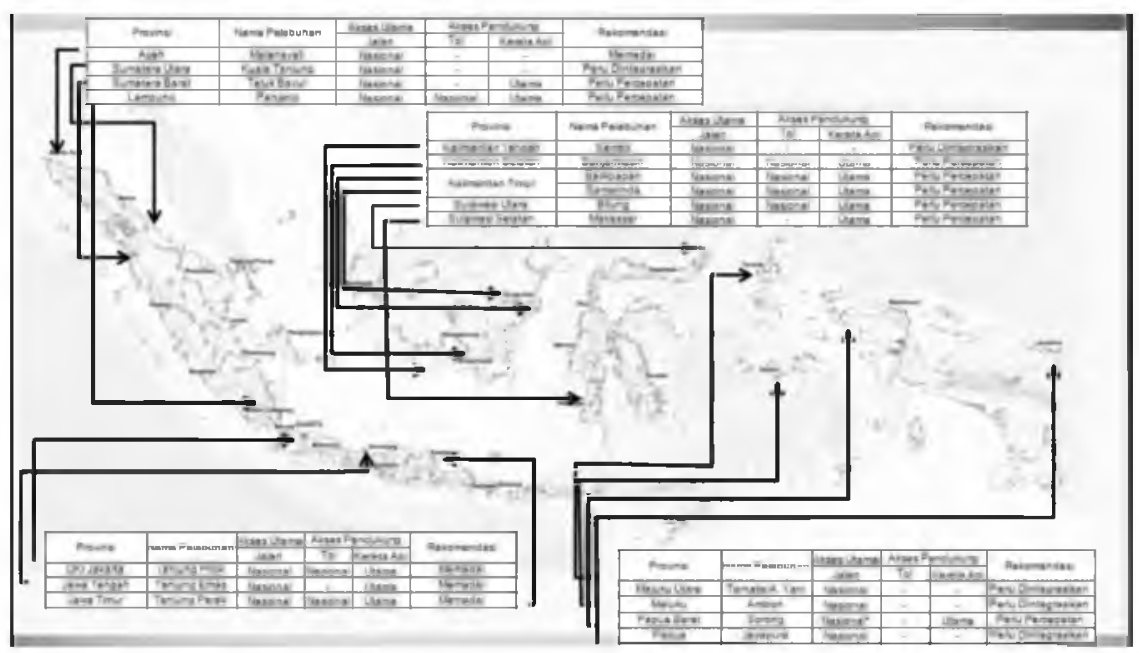

Gambar 5. Akses Pendukung Pelabuhan

(Sumber: Balitbang Kemenhub RI, 2015)

\subsection{Indikator Konektivitas Bandar Udara dan Konektivitas Antarmoda}

Dari hasil survey dan pengolahan data selanjutnya dapat dibuat indikator konektivitas bandara Indonesia dan matriks yang menunjukkan konektivitas antarmoda dari Bandara Transit menuju kota tujuan.

Melihat Gambar 6 terlihat bahwa bandara di ibu kota propinsi dan di Pulau Jawa mempunyai indikator konektivitas tinggi, sedangkan bandara di luar Pulau Jawa mempunyai indikator konektivitas lebih rendah. Bandara luar Pulau Jawa yang mempunyai indikator konektivitas yang tinggi diantaranya adalah Hasanuddin, Makasar (UPG); Kualanamu, Medan (KNO); Sepinggan, Balikpapan (BPN); dan Ngurah Rai, Denpasar.

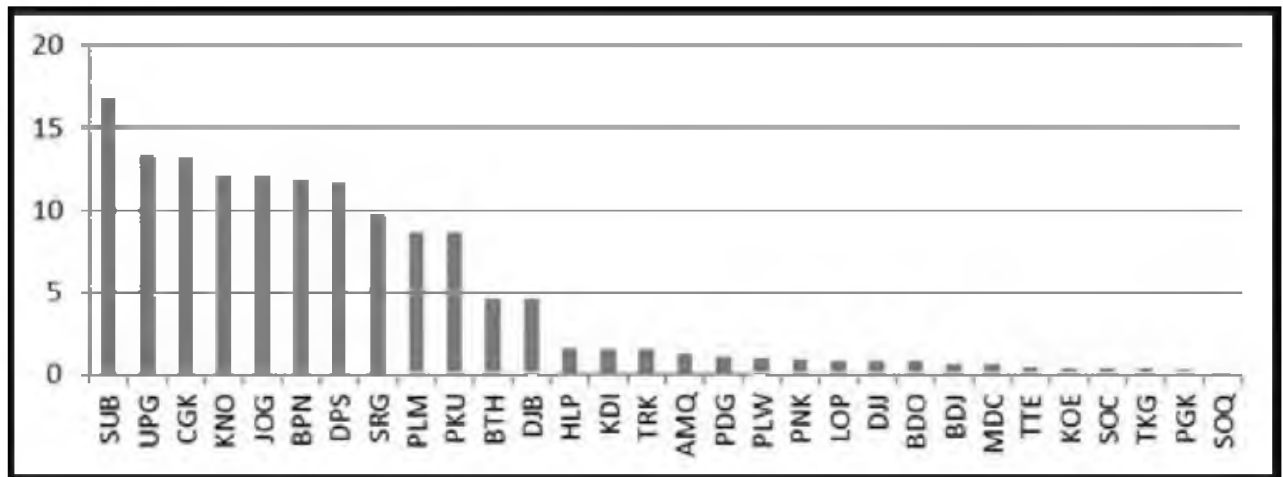

Gambar 6. Indikator Konektifitas Bandar Udara di Indonesia

Di sisi lain, bandara dengan nilai konektivitas yang tinggi akan memberikan dampak yang lebih luas dan besar kepada jaringan transportasi udara nasional saat terjadi penutupan bandara karena terjadinya bencana alam ataupun penyebab lainnya. Bila bandara dengan nilai konektivitas tinggi harus ditutup maka semakin banyak bandara lainnya yang ikut terdampak seperti terjadinya keterlambatan ataupun pembatalan penerbangan. 
Guna mengantisipasi saat terjadinya penutupan bandara maka diperlukan bandarabandara alternatif yang mampu menampung penerbangan baik dari sisi pesawat udara ataupun penumpangnya. Bandara alternatif harus mampu menampung tipe pesawat dan juga jumlahnya serta jumlah penumpang dan ketersediaan moda transportasi lainnya yang dapat digunakan untuk melanjutkan perjalanan menuju kota tujuan.

Tabel 2. Konektivitas Tinggi Antarmoda Bandara Transit - Tujuan

\begin{tabular}{|c|c|c|c|}
\hline \multirow{2}{*}{ No. } & \multicolumn{2}{|c|}{ Bandara } & \multirow{2}{*}{$\begin{array}{c}\text { Penghubung } \\
\text { Alternatif-Tujuan }\end{array}$} \\
\hline & Tujuan & Alternatif & \\
\hline \multirow{2}{*}{1} & Bandung & Cengkareng & Kereta Api-Jalan \\
\hline & Bandung & Halim & Kereta Api-Jalan \\
\hline 2 & Balikpapan & Samarinda & Jalan \\
\hline 3 & Banjarmasin & Palangkaraya & Jalan \\
\hline 4 & Batam & Tanjung Pinang & Penyeberangan \\
\hline 5 & Bima & Sumbawa & Jalan \\
\hline 6 & Ende & Maumere & Jalan \\
\hline \multirow{4}{*}{7} & Jakarta (Cengkareng) & Halim P. & Jalan \\
\hline & Jakarta (Cengkareng) & Bandung & Kereta Api \& Jalan \\
\hline & Jakarta (Cengkareng) & Pondok Cabe & Jalan \\
\hline & Jakarta (Cengkareng) & Curug & Jalan \\
\hline 8 & Jember & Banyuwangi & Jalan \\
\hline 9 & Larantuka & Maumere & Jalan \\
\hline 10 & Malang & Surabaya & Kereta Api \& Jalan \\
\hline 11 & Medan & Polonia & Kereta Api \& Jalan \\
\hline 12 & Palangkaraya & Banjarmasin & Jalan \\
\hline 13 & Samarinda & Balikpapan & Jalan \\
\hline \multirow[t]{2}{*}{14} & Semarang & Yogyakarta & Jalan \\
\hline & Semarang & Solo & Jalan \\
\hline \multirow[t]{2}{*}{15} & Solo & Yogyakarta & Kereta Api \& Jalan \\
\hline & Solo & Semarang & Jalan \\
\hline 16 & Sumbawa & Bima & Jalan \\
\hline 17 & Surabaya & Malang & Jalan \\
\hline \multirow[t]{2}{*}{18} & Yogyakarta & Solo & Kereta Api \& Jalan \\
\hline & Yogyakarta & Semarang & Jalan \\
\hline 19 & Sampit & Palangkaraya & Jalan \\
\hline \multirow[t]{4}{*}{20} & Jakarta (Halim P.) & Cengkareng & Jalan \\
\hline & Jakarta (Halim P.) & Bandung & Kereta Api \& Jalan \\
\hline & Jakarta (Halim P.) & Pondok Cabe & Jalan \\
\hline & Jakarta (Halim P.) & Curug & Jalan \\
\hline 21 & Sabang & Banda Aceh & Jalan \\
\hline 22 & Tapanuli Utara & Sibolga & Jalan \\
\hline 23 & Kolaka & Kendari & Jalan \\
\hline 24 & Maumere & Ende & Jalan \\
\hline
\end{tabular}


Tabel 3. Konektivitas Menengah Antarmoda Bandara Transit - Tujuan

\begin{tabular}{|c|c|c|c|}
\hline \multirow{2}{*}{ No. } & \multicolumn{2}{|c|}{ Bandara } & \multirow{2}{*}{$\begin{array}{c}\text { Penghubung Alternatif } \\
\text { Tujuan }\end{array}$} \\
\hline & Tujuan & Alternatif & \\
\hline 1 & Banda Aceh & Medan & Jalan \\
\hline 2 & Balikpapan & Banjarmasin & Jalan \\
\hline 3 & Banjarmasin & Balikpapan & Jalan \\
\hline 4 & Banyuwangi & Malang & Jalan \\
\hline \multirow{2}{*}{5} & \multirow{2}{*}{ Bengkulu } & Jambi & Jalan \\
\hline & & Palembang & Jalan \\
\hline 6 & Denpasar & Surabaya & Penyeberangan \\
\hline 7 & Ende & Labuhanbajo & Jalan \\
\hline 8 & Fak Fak & Sorong & Penyeberangan \\
\hline 9 & Gorontalo & Manado & Jalan \\
\hline 10 & Kupang & Atambua & Jalan \\
\hline 11 & Lampung & Jakarta & Penyeberangan \\
\hline 12 & Jambi & Palembang & Jalan \\
\hline 13 & Makassar & Mamuju & Jalan \\
\hline 14 & Manado & Gorontalo & Jalan \\
\hline 15 & Mataram & Bali & Penyeberangan \\
\hline 16 & Padang & Pekanbaru & Jalan \\
\hline 17 & Pangkal pinang & Tanjung Pandan & Penyeberangan \\
\hline 18 & Palembang & Jambi & Jalan \\
\hline 19 & Pekanbaru & Padang & Jalan \\
\hline 20 & Sorong & Fak Fak & Penyeberangan \\
\hline 21 & Surabaya & Bali & Penyeberangan \\
\hline 22 & Tarakan & Balikpapan & Penyeberangan \\
\hline 23 & Waingapu & Ende & Penyeberangan \\
\hline 24 & Tanjung Pinang & Batam & Penyeberangan \\
\hline 25 & Tanjang Pandan & Pangkal Pinang & Penyeberangan \\
\hline 26 & Pangkal Pinang & Tanjung Pandan & Penyeberangan \\
\hline 27 & Kotabaru & Banjarmasin & Jalan \\
\hline 28 & Ngada & Ende & Jalan \\
\hline 29 & Gunung Sitoli & Sibolga & Penyeberangan \\
\hline 30 & Meulaboh & Banda Aceh & Jalan \\
\hline 31 & Sibolga & Gunung Sitoli & Penyeberangan \\
\hline 32 & Saumlaki & Langgur & Penyeberangan \\
\hline 33 & Langgur & Saumlaki & Penyeberangan \\
\hline 34 & Ketapang & Pontianak & Jalan \\
\hline 35 & Mamuju & Makasar & Jalan \\
\hline
\end{tabular}


Tabel 4. Konektivitas Rendah Antarmoda Bandara Transit - Tujuan

\begin{tabular}{cllc}
\hline \multirow{2}{*}{ No. } & \multicolumn{2}{c}{ Bandara } & $\begin{array}{c}\text { Penghubung Alternatif- } \\
\text { Tujuan }\end{array}$ \\
\cline { 2 - 4 } 1 & Tujuan & Alternatif & Laut \\
\hline 2 & Jayapura & Ternate & Laut \\
\hline 3 & Luwuk & Biak & Jalan \\
\hline 4 & Kaimana & Palu & Laut \\
\hline 5 & Kendari & Fak-fak & Jalan \\
\hline 6 & Labuan bajo & Makasar & Laut \\
\hline 7 & Medan & Bima & Jalan \\
\hline 8 & Nabire & Aceh & Laut \\
\hline 9 & Palu & Manokwari & Jalan \\
\hline 10 & Pontianak & Makassar & Jalan \\
\hline 11 & Wamena & Palangkaraya & Jalan \\
\hline 12 & Ternate & Jayapura & Laut \\
\hline 13 & Tual & Manado & Laut \\
\hline 14 & Bau-bau & Dobo & Laut \\
\hline 15 & Timika & Makasar & Laut \\
\hline 16 & Berau & Fakfak & Jalan \\
\hline 17 & Ternate & Balikpapan & Laut \\
\hline 18 & Tobelo & Tobelo & Laut \\
\hline
\end{tabular}

Dari Tabel 2, Tabel 3 dan Tabel 4 diperlihatkan masing-masing tingkat konektivitas bandara alternatif dengan kota tujuan. Konektivitas antarmoda dari bandara transit ke tujuan dibagi dalam 3 (tiga) kategori. Konektivitas tinggi (Tabel 2) didominasi bandara di pulau jawa yang didukung jalan darat dan kerata api yang sangat baik, konektivitas menengah (Tabel 3) terjadi di bandara yang dihubungkan jalan cukup baik dan penyeberangan, sedangkan konektivitas rendah terjadi di bandara yang dihubungkan dengan kapal laut.

Bandara alternatif yang memiliki konektivitas baik dengan kota tujuan akan memberikan kemudahan penumpang dalam melanjutkan perjalanan ke kota tujuan saat terjadi penutupan bandara tujuan. Walau demikian perlu diperhatikan kapasitas bandara alternatif apakah mampu menampung pesawat udara ataupun penumpang limpahan apalagi bila penutupan bandara tujuan terjadi dalam jangka waktu yang lama.

Sebaliknya bandara alternatif yang memiliki konektivitas rendah dengan kota tujuan tidak direkomendasikan kecuali bila memang penutupan bandara tujuan terjadi dalam jangka waktu yang lama sehingga dengan terpaksa menggunakan bandara alternatif tersebut yang selanjutnya disambung menggunakan moda transportasi lain menuju kota tujuan. 


\section{Kesimpulan}

Sebagai negara dengan resiko kebencanaan yang tinggi, sejak dini Indonesia harus merencanakan mitigasi bencana, terutama pada sisi jaringan transportasi udara. Transportasi udara sangat rentan terhadap pengaruh akibat bencana terutama pada aspek penutupan bandara. Penutupan bandara dengan konektivitas antar bandara tinggi akan lebih banyak pengaruhnya terhadap jaringan dibandingkan dengan yang memiliki konektivitas antar bandara rendah. Secara umum bandara pengumpul akan memiliki konektivitas lebih tinggi.

Ketersediaan bandara alternatif akan membantu upaya mitigasi tersebut. Kualitas mitigasi ditentukan oleh konektivitas bandara alternatif ke kota tujuan menggunakan moda transportasi lain. Konektivitas bandara menggunakan moda transportasi lain di Pulau Jawa relatif lebih baik karena selain prasarana jalan yang memadai juga tersedia angkutan kereta api yang menghubungkan kota-kota besar.

Penelitian lanjutan tentang pengembangan model simulasi transportasi udara yang diintegrasikan dengan moda transportasi lain perlu dilakukan. Model simulasi tersebut diharapkan dapat memodelkan respon jaringan transportasi udara saat terjadi penutupan bandara karena force majeur. Dengan model simulasi tersebut maka akan dapat direncanakan langkah mitigasi yang paling tepat disertai dengan upaya optimasi biaya.

\section{Ucapan Terima Kasih}

Penulis mengucapkan banyak terima kasih kepada Kementerian Riset, Teknologi dan Pendidikan Tinggi yang telah memberikan dukungan finansial terhadap penelitian ini melalui Program Penelitian Hibah Bersaing Tahun 2016.

\section{Daftar Pustaka}

Black, J.A. (1981), "Urban Transport Planning: Theory and Practice", London, Cromm Helm

Guida M. and Funaro M., "Topology of the Italian Airport Network", Chaos, Solitons \& Fractals, Vol. 31, p.p. 527-536 (2007).

Guimera R., Mossa S., Turtschi A. and Amaral L. A. N., "The worldwide air transportation network, Anomalous centrality, community structure and cities" global roles." PNAS. Vol. 2 7794-7799 (2005).

Gunawan, Medianto R, (2015), "Pemodelan Simulasi Jaringan Transportasi Udara Nasional", Proseding RETII ISSN 1907-5995, Yogyakarta

Haggett, P., (2001), “Geography a Global Synthesis”, Prentice Hall, New York.

Hurst, Elliot, (1974), “A Geography of Economic Behavior : An Introduction”, Prentice Hall, London.

Smyth,M., Pearce,B.,(2007), "IATA Economics Briefing No 8: Aviation Economic Benefits", IATA.

Janic M., “Air Transport System Analysis and Modelling”, Gordon and Breach Science Publishers, Amsterdam(2000). 
Jinca, M.Y , L.Frianto, \& Aksa S.K., (2002), "Sistem Transportasi Laut Kawasan Timur Indonesia", Sci\&Tech, Vol 3 no.2, 47 - 60.

Li W., Chai X., "Statistical analysis of airport network of China". Phys. Rev.E. 69046106 (2004)

Malighetti G., Martini G., Paleari S. and Redondi R., "The Impacts of Airport Centrality in the EU Network and Inter- Airport Competition on Airport Efficiency", MPRA (2009).

Marlok, E.K., (1985), "Pengantar Teknik dan perencanaan Transportasi (cetakan 1995)”, PT. Gelora Aksara Pratama, Jakarta.

Rodrigue, J.P, Claude, C \& Brian S., (2006), “The Geography of Transport Systems”, Routledge, London and New York.

Sapre M., "Topological Analysis of Air Transportation Networks", Master of Science Thesis in Computational Natural Science, Institute of Information Technology Hyderabad, India (2011).

Tamin, O.Z. (2000), Perencanaan dan Pemodelan Transportasi, Penerbit ITB, Bandung. 